\title{
Efficacy and safety of rufinamide in pediatric epilepsy
}

\author{
David T. Hsieh and Elizabeth A. Thiele
}

\begin{abstract}
Rufinamide is a novel anticonvulsant medication approved by the US Food and Drug Administration (FDA) in 2008 for the treatment of seizures associated with Lennox-Gastaut syndrome in patients 4 years of age and older, based upon clinical trials demonstrating clinical efficacy and tolerability. Rufinamide is especially effective for tonic-atonic seizures in LennoxGastaut syndrome, but is subsequently proving to be safe and effective in clinical practice for a broad patient population with refractory epilepsy. Although further research and clinical experience is needed, rufinamide holds the promise to positively impact the care of children with epilepsy. In this review, we review the use of rufinamide in pediatric epilepsy, with a focus on efficacy and safety.
\end{abstract}

Keywords: anticonvulsants, epilepsy, Lennox-Gastaut syndrome, rufinamide

\section{Introduction and history}

Rufinamide [1-(2,6-difluoro-phenyl) methyl-1 hydro-1,2,3-triazole-4 carboxamide] is a novel anticonvulsant medication which, as a triazole derivative, is structurally unrelated to any other currently used anticonvulsant medication. In 2004, rufinamide was designated as an orphan drug for adjunctive use in the treatment of seizures associated with Lennox-Gastaut syndrome (LGS) in patients 4 years of age and older by the United States Food and Drug Administration (FDA). In 2007, rufinamide was approved for use in Europe, and this was followed by approval by the FDA in November 2008 as adjunctive treatment of seizures associated with LGS in patients 4 years of age and older. This marked the first time that a new anticonvulsant medication was available for use in the United States with an initial pediatric indication.

\section{Proposed mechanism of action}

Preclinical animal studies suggest the mechanism of action to include, at least in part, the prolongation of the recovery of sodium channels from the inactivated state, with a resultant decrease of the frequency of sustained repetitive firing in neurons [McLean et al. 2005]. Oral rufinamide has shown anticonvulsant activity in a broad spectrum of animal models to include pentylene-tetrazol-induced and maximal electroshock-induced seizures in mice, suggesting the possibility of broad anticonvulsant properties in humans [White et al. 2008].

\section{Characteristics}

Rufinamide is well absorbed ( $>85 \%$ ) with oral administration (Table 1). Absorption may be slightly less, however, with incremental dose increases over $600 \mathrm{mg}$ [Perucca et al. 2008], but this effect is likely not clinically significant. Peak plasma concentration occurs within 4-6 hours. Plasma protein binding is low (26-34\%) and rufinamide does not affect the cytochrome P450 enzyme system [Perucca et al. 2008]. Metabolism is extensive ( $<2 \%$ is excreted unmetabolized) and occurs via hepatic hydrolysis of the carboxamide group by carboxylesterases, forming a metabolically inactive intermediate which is cleared renally. The elimination of rufinamide occurs with a plasma half-life of 6-10 hours.

\section{Clinical efficacy}

Several large, randomized, placebo-controlled trials have been published evaluating rufinamide as an adjunctive treatment in older adolescents and adults for partial-onset seizures, demonstrating significant differences in favor of rufinamide versus placebo in responder rates (defined as a $50 \%$
Ther Adv Neurol Disord

(2013) 6(3) 189-198

DOI: $10.1177 /$

1756285613481083

(c) The Author(s), 2013. Reprints and permissions: http://www.sagepub.co.uk/ journalsPermissions.nav

Correspondence to: Elizabeth A. Thiele, MD, PhD

Pediatric Epilepsy

Program, Department of Neurology, Massachusetts General Hospital, 175 Cambridge Street, Suite 340, Boston, MA 021142796, USA.

ethieleapartners.org

David T. Hsieh, MD Department of Neurology, Massachusetts General Hospital, Boston, MA, USA 
Table 1. Rufinamide characteristics summary.

Bioavailability:
Approximately $85 \%$, orally
Peak plasma concentration:
4-6 hours
Plasma protein binding:
26-34\%
Half-life:
6-10 hours
Metabolism:
Hepatic
Extensively (<2\% unmetabolized)
No involvement of cytochrome P450
No autoinduction
Excretion:
Urine

or greater reduction in seizure frequency) [Palhagen et al. 2001; Brodie et al. 2009; Elger et al. 2010; Biton et al. 2011], and with a significant linear trend of dose response [Elger et al. 2010]. A recent meta-analysis also supports the efficacy of rufinamide as adjunctive therapy in patients with medication-refractory epilepsy [Verrotti et al. 2011]. Only one randomized, placebo-controlled trial involving mostly children has been published, evaluating the use of rufinamide in the treatment of seizures associated with LGS [Glauser et al. 2008]. This consequential data, however, advanced the FDA approval in 2008 for the adjunctive treatment of seizures associated with LGS (in patients 4 years old and older).

Rufinamide, as such, is now clinically available to contribute to a longstanding unmet need in the treatment of pediatric epilepsy: the treatment of refractory seizures in LGS. LGS is a childhood epileptic encephalopathy, of heterogeneous etiologies, which is characterized by multiple seizure types (most commonly tonic, atypical absence, and drop attacks), electroencephalogram findings of a slow spike-and-wave pattern, and cognitive impairment [Camfield, 2011]. In addition to rufinamide, the FDA has approved felbamate, lamotrigine, topiramate, and clobazam for the treatment of LGS, although many consider valproic acid to be a first-line therapy [Montouris, 2011]. However, the multiple seizure types in LGS are often refractory to treatment, and the optimum treatment of seizures associated with LGS is awaiting further refinement and establishment [Hancock and Cross, 2009]. Some seizure types in LGS, such as atypical absence, can occur so frequently that they are near impossible to count. Thus, many studies involving rufinamide and LGS have focused on certain more easily countable seizures, such as 'drop attack' seizures, in addition to parental estimates of total seizures. The term 'tonic-atonic' seizures has been agreed upon by an international panel of child neurologists as a suitable nomenclature for 'drop attacks', due to the difficulty that caregivers can have in separating tonic and atonic seizures [Glauser et al. 2008]. In addition to their ability to be counted, drop attack seizures are a clinically significant outcome due to their relatively higher potential for injury [French et al. 2004].

\section{Randomized, placebo-controlled trial}

In 2008, Glauser and colleagues published their double-blind, randomized, placebo-controlled trial of rufinamide in patients with LGS [Glauser et al. 2008]. In this study, there were 74 patients randomized to adjunctive rufinamide, with an age range of 4-37 years old (median 12 years old), and 64 to placebo. The approximate target dosing was $45 \mathrm{mg} / \mathrm{kg} /$ day, achieved by $87.8 \%$ of the rufinamide-treated group, up to $3200 \mathrm{mg}$ a day. After a 12-week parallel-group treatment period, the median percentage decrease in caregiver-reported total countable seizures per 28 days for those treated with rufinamide was $32.7 \%$, compared with $11.7 \%$ with placebo $(p=0.0015)$. Responder rates for total seizures were higher in the rufinamide group $(31.1 \%)$ versus placebo $(10.9 \%)(p=$ $0.0045)$. Efficacy for tonic-atonic seizures was especially prominent, with a median percentage decrease per 28 days with rufinamide of $42.5 \%$ compared to an increase of $1.4 \%$ in the placebo group $(p<0.0001)$. Although $4.1 \%$ treated with rufinamide achieved complete cessation of tonicatonic seizures, $3.3 \%$ in the placebo group did also $(p=0.8414)$, and no patients achieved complete seizure freedom. In regards to partial seizures, there was a median percentage decrease per 28 days with rufinamide of $71.9 \%$ compared with $11.1 \%$ in the placebo group; however, a $p$-value was not assigned, as less than $20 \%$ of the population reported partial seizures. Furthermore, based upon a seven-point Likert scale, caregivers rated a greater decrease in seizure severity with rufinamide versus placebo $(p=0.0041)$.

This study published by Glauser and colleagues is the only double-blind, randomized, placebo-controlled rufinamide study involving mostly 
Table 2. Summary of published pediatric rufinamide studies.

\begin{tabular}{|c|c|c|c|c|}
\hline Reference & Study design & Population & Countable seizure outcome & $\begin{array}{l}\text { Adverse events: Total } \\
\text { patients, most common }\end{array}$ \\
\hline $\begin{array}{l}\text { Glauser et al. } \\
\text { [2008] }\end{array}$ & $\begin{array}{l}\text { Randomized } \\
\text { Double-blind } \\
\text { Placebo- } \\
\text { controlled }\end{array}$ & $\begin{array}{l}74 \text { rufinamide patients } \\
\text { Age } 4-35 \text { years } \\
\text { LGS }\end{array}$ & $\begin{array}{l}\geq 50 \% \text { decrease: } 31.1 \% \\
\text { Seizure-free: none }\end{array}$ & $\begin{array}{l}\text { Total } 81.1 \% \\
\text {-Somnolence } 24.3 \% \\
\text {-Vomiting } 21.6 \%\end{array}$ \\
\hline $\begin{array}{l}\text { Kluger et al. } \\
\text { [2009] }\end{array}$ & $\begin{array}{l}\text { Retrospective } \\
\text { 12-week } \\
\text { Observational }\end{array}$ & $\begin{array}{l}60 \text { patients } \\
\text { Age } 1-50 \text { years } \\
\text { Mixed epilepsy types }\end{array}$ & $\begin{array}{l}\geq 50 \% \text { decrease } 46.7 \% \\
\text { Seizure-free } 8.3 \%\end{array}$ & $\begin{array}{l}\text { Total } 58.3 \% \\
\text {-Fatigue } 18.3 \% \\
\text {-Vomiting } 13.3 \% \\
\text {-Loss of appetite } 10 \%\end{array}$ \\
\hline $\begin{array}{l}\text { Coppola et al. } \\
\text { [2010] }\end{array}$ & $\begin{array}{l}\text { Prospective } \\
\text { Open-label }\end{array}$ & $\begin{array}{l}43 \text { patients } \\
\text { Age } 4-34 \text { years } \\
\text { LGS }\end{array}$ & $\begin{array}{l}\geq 50 \% \text { decrease: } 60.5 \% \\
\text { Seizure-free: } 9.3 \%\end{array}$ & $\begin{array}{l}\text { Total } 23.2 \% \\
\text {-Vomiting } 13.5 \% \\
\text {-Irritability } 6.9 \% \\
\text {-Drowsiness } 2.3 \%\end{array}$ \\
\hline $\begin{array}{l}\text { Kluger et al. } \\
\text { [2010a] }\end{array}$ & $\begin{array}{l}\text { Open-label } \\
\text { extension } \\
\text { study }\end{array}$ & $\begin{array}{l}124 \text { patients } \\
\text { Age } 4-37 \text { years } \\
\text { LGS }\end{array}$ & $\begin{array}{l}\geq 50 \% \text { decrease: } \\
41 \% \text { during last } 12 \text { months } \\
\text { Seizure-free: none }\end{array}$ & $\begin{array}{l}\text { Total } 91.1 \% \\
\text {-Vomiting } 30.6 \% \\
\text {-Pyrexia } 25.8 \% \\
\text {-Somnolence } 21 \%\end{array}$ \\
\hline $\begin{array}{l}\text { Kluger et al. } \\
\text { [2010b] }\end{array}$ & $\begin{array}{l}\text { Retrospective } \\
\text { 18-month } \\
\text { Observational }\end{array}$ & $\begin{array}{l}52 \text { patients } \\
\text { Age } 1-50 \text { years } \\
\text { Mixed epilepsy types }\end{array}$ & $\begin{array}{l}\geq 50 \% \text { decrease } 26.7 \% \\
\text { Seizure-free: } 1.6 \%\end{array}$ & $\begin{array}{l}\text { Total } 61.6 \% \\
\text {-Fatigue } 18.3 \% \\
\text {-Vomiting } 15 \% \\
\text {-Loss of appetite } 10 \%\end{array}$ \\
\hline $\begin{array}{l}\text { Vendrame } \\
\text { et al. [2010] }\end{array}$ & Retrospective & $\begin{array}{l}77 \text { patients } \\
\text { Age } 1-27 \text { years } \\
\text { Mixed epilepsy types }\end{array}$ & $\begin{array}{l}\geq 50 \% \text { decrease: } 51 \% \\
\text { Seizure-free: not reported }\end{array}$ & $\begin{array}{l}\text { Total } 29 \% \\
\text {-Drowsiness 13\% } \\
\text {-Rash } 6 \%\end{array}$ \\
\hline $\begin{array}{l}\text { Coppola et al. } \\
\text { [2011] }\end{array}$ & $\begin{array}{l}\text { Prospective } \\
\text { Open-label }\end{array}$ & $\begin{array}{l}38 \text { patients } \\
\text { Age } 4-34 \text { years } \\
\text { Non-LGS epileptic } \\
\text { encephalopathies }\end{array}$ & $\begin{array}{l}\geq 50 \% \text { decrease: } 39.5 \% \\
\text { Seizure-free: } 2.6 \%\end{array}$ & $\begin{array}{l}\text { Total: } 28.9 \% \\
\text {-Vomiting } 13.1 \% \\
\text {-Irritability } 5.3 \% \\
\text {-Drowsiness } 5.3 \%\end{array}$ \\
\hline $\begin{array}{l}\text { Hausler et al. } \\
\text { [2011] }\end{array}$ & Retrospective & $\begin{array}{l}3 \text { patients } \\
\text { Age } 2-4 \text { years } \\
\text { EMA }\end{array}$ & $\begin{array}{l}\geq 50 \% \text { decrease: } 100 \% \\
\text { Seizure-free: } 66.6 \%\end{array}$ & 'Transient and mild' \\
\hline $\begin{array}{l}\text { Joseph et al. } \\
\text { [2011] }\end{array}$ & Retrospective & $\begin{array}{l}45 \text { patients } \\
\text { Age } 1-20 \text { years } \\
\text { Mixed epilepsy types }\end{array}$ & $\begin{array}{l}\geq 50 \% \text { decrease: } 46 \% \\
\text { Seizure-free: none }\end{array}$ & $\begin{array}{l}\text { Total: not reported } \\
\text {-Vomiting } 4.4 \% \\
\text {-Loss of appetite } 4.4 \% \\
\text {-Agitation } 4.4 \%\end{array}$ \\
\hline $\begin{array}{l}\text { Mueller et al. } \\
\text { [2011] }\end{array}$ & Retrospective & $\begin{array}{l}20 \text { patients } \\
\text { Age } 3-23 \text { years } \\
\text { Dravet syndrome }\end{array}$ & $\begin{array}{l}\geq 50 \% \text { decrease at } 6 \text { months: } \\
20 \% \\
\geq 50 \% \text { decrease at } 18 \\
\text { months: } 5 \%\end{array}$ & $\begin{array}{l}\text { Total } 40 \% \\
\text {-Decreased appetite } 15 \% \\
\text {-Fatigue } 10 \% \\
\text {-Behavior change } 10 \%\end{array}$ \\
\hline $\begin{array}{l}\text { Olson et al. } \\
\text { [2011] }\end{array}$ & Retrospective & $\begin{array}{l}38 \text { patients } \\
1-23 \text { years } \\
\text { Epileptic spasms }\end{array}$ & $\begin{array}{l}\geq 50 \% \text { decrease in spasms: } \\
53 \% \\
>99 \% \text { decrease: } 5 \%\end{array}$ & $\begin{array}{l}\text { Total } 37 \% \\
\text {-Decreased appetite } 7.9 \% \\
\text {-Sedation } 7.9 \%\end{array}$ \\
\hline $\begin{array}{l}\text { Vendrame } \\
\text { et al. [2011] }\end{array}$ & Retrospective & $\begin{array}{l}5 \text { patients } \\
\text { Age } 2-3 \text { years } \\
\text { MMPEI }\end{array}$ & $\begin{array}{l}\geq 50 \% \text { decrease: } 40 \% \\
\text { Seizure-free: none }\end{array}$ & $\begin{array}{l}\text { Total: } 40 \% \\
\text {-Vomiting } 20 \% \\
\text {-Loss of appetite } 20 \%\end{array}$ \\
\hline $\begin{array}{l}\text { Kim et al. } \\
{[2012]}\end{array}$ & $\begin{array}{l}\text { Prospective } \\
\text { Open-label } \\
\text { Observational }\end{array}$ & $\begin{array}{l}128 \text { patients } \\
\text { Age } 1-19 \text { years } \\
\text { LGS }\end{array}$ & $\begin{array}{l}\geq 50 \% \text { decrease: } 35.9 \% \\
\text { Seizure-free: } 7.8 \%\end{array}$ & $\begin{array}{l}\text { Total } 32.8 \% \\
\text {-Fatigue } 11.7 \% \\
\text {-Loss of appetite } 7 \%\end{array}$ \\
\hline $\begin{array}{l}\text { Lee et al. } \\
\text { [2012] }\end{array}$ & Retrospective & $\begin{array}{l}88 \text { patients } \\
\text { Age } 2-43 \text { years } \\
\text { Mixed epilepsy types }\end{array}$ & $\begin{array}{l}\geq 50 \% \text { decrease: } 54,6 \% \\
\text { Seizure-free: } 2.3 \%\end{array}$ & $\begin{array}{l}\text { Total: } 31.8 \% \\
\text { - Loss of appetite } 8 \% \\
\text { - Somnolence } 6.8 \%\end{array}$ \\
\hline
\end{tabular}


Table 2. (Continued)

\begin{tabular}{|c|c|c|c|c|}
\hline Reference & Study design & Population & Countable seizure outcome & $\begin{array}{l}\text { Adverse events: Total } \\
\text { patients, most common }\end{array}$ \\
\hline \multirow{2}{*}{$\begin{array}{l}\text { Moavero et al. } \\
\text { [2012] }\end{array}$} & Prospective & 70 patients & $\geq 50 \%$ decrease: $38.5 \%$ & Total $24.3 \%$ \\
\hline & Open-label & $\begin{array}{l}\text { Age } 3-21 \text { years } \\
\text { Partial-onset seizures }\end{array}$ & Seizure-free: $4.3 \%$ & $\begin{array}{l}\text { - Drowsiness } 22.8 \% \\
\text { - Vomiting } 10 \%\end{array}$ \\
\hline $\begin{array}{l}\text { von } \\
\text { Stulpnagel } \\
\text { et al. [2012] }\end{array}$ & Retrospective & $\begin{array}{l}8 \text { patients } \\
\text { Age } 3-20 \text { years } \\
\text { Doose syndrome }\end{array}$ & $\begin{array}{l}\geq 50 \% \text { decrease: } 75 \% \text { at } 6 \\
\text { months, } 62.5 \% \text { at } 12 \text { months } \\
\text { Seizure-free: none }\end{array}$ & $\begin{array}{l}\text { Total } 25 \% \\
\text {-Sleepiness } 12.5 \% \\
\text {-Decreased appetite } \\
12.5 \%\end{array}$ \\
\hline
\end{tabular}

children [Glauser et al. 2008]. Although this type of study design is considered the most scientifically rigorous, positive efficacy results are not automatically translated into effectiveness in clinical practice, due to the set patient population, titration and dosing schedules, and follow-up periods that are rigidly maintained within the boundaries of clinical trials. Thus, of complimentary importance in supporting the clinical effectiveness of rufinamide are the open-label extension study and the several observational and retrospective studies (Table 2) that have subsequently been published:

\section{Prospective open-label studies in LGS}

In the open-label extension of the original randomized controlled study, converting placebotreated patients into a rufinamide-treated group, 124 patients, with an age range of 4-37 years old (mean 14.2 years old), were treated with adjunctive rufinamide for 10 to 1149 days (median 432 days) [Glauser et al. 2008; Kluger et al. 2010a]. During the open-label period, dosing adjustments were made at the investigator's discretion, with a median dosing of $52.9 \mathrm{mg} / \mathrm{kg} /$ day. During the last 12 months of treatment, the responder rates were $41 \%$ for total seizures and $47.9 \%$ for tonic-atonic seizures. The importance of this extension study was the demonstration of sustained efficacy over a longer time period, although still within the same limited patient population.

Two additional prospective open-label studies have also evaluated adjunctive rufinamide in LGS. In one of these studies, 43 patients with LGS, with an age range of 4-34 years old (median 15 years old) were treated with adjunctive rufinamide for 3 to 21 months (mean 12.3 months) [Coppola et al. 2010]. The final mean dosing was $33.5 \mathrm{mg} / \mathrm{kg} / \mathrm{day}$ if combined with valproic acid and $54.5 \mathrm{mg} / \mathrm{kg} /$ day if not. The response rate for countable seizures was $60.5 \%$ after a mean 12 -month observational period. The response rate for drop seizures was $46.5 \%$. In another study, 128 patients with LGS, with an age range of 1-19 years old (mean 9.4 years old) were treated with adjunctive rufinamide over a 12-week maintenance treatment period [Kim et al. 2012]. The final mean dosing was $31.7 \mathrm{mg} / \mathrm{kg} /$ day. The response rate for overall seizures was $35.9 \%$. The response rate for drop seizures was $36.5 \%$. These two studies confirmed the efficacy of rufinamide for seizures in LGS, but with a separate study population.

\section{Prospective open-label studies in broader patient populations}

In a prospective open-label study, 38 patients, with an age range of 4-34 years old (median 12.5 years old), with different types of childhood-onset refractory epileptic encephalopathies were treated with adjunctive rufinamide for 3-26 months (mean 11.4 months) [Coppola et al. 2011]. The final mean dosing was $37.9 \mathrm{mg} / \mathrm{kg} /$ day if combined with valproic acid and $36.4 \mathrm{mg} / \mathrm{kg} /$ day if not. This patient population included 22 patients with a multifocal encephalopathy with spasms/ tonic seizures, eleven patients with a multifocal encephalopathy with bifrontal spike-wave discharges, four patients with Dravet syndrome, and one patient with Doose syndrome. The overall response rate for countable seizures was $39.5 \%$.

In another prospective open-label study, 70 patients, with an age range of 3-21 years old (mean 10.7 years old), with refractory partial-onset seizures were treated with adjunctive rufinamide for and followed for 12 months [Moavero et al. 2012]. The final mean dosing was $42.6 \mathrm{mg} / \mathrm{kg} /$ day if combined with valproic acid and $31.8 \mathrm{mg} / \mathrm{kg} /$ day if not. At 12 months the overall seizure response rate was $38.5 \%$. The importance of these studies was 
the expansion of the identified efficacy of rufinamide into a broader pediatric patient population outside of LGS.

\section{Retrospective studies in broader patient populations}

Several retrospective studies examining the broad clinical use of rufinamide in pediatric epilepsy have also been published. In an open-label retrospective study, 60 patients, with an age range of 1-50 years old (median 11 years old), with various epilepsy syndromes, were treated with adjunctive rufinamide with results reported at 12 weeks [Kluger et al. 2009], and with further results for 52 out of 60 of the same patient cohort reported at 18 months [Kluger et al. 2010b]. The median maintenance dosing was $35.5 \mathrm{mg} / \mathrm{kg} /$ day. At 12 weeks, the overall seizure response rate for seizure reduction was $46.7 \%$, with the highest rate in patients with LGS (54.8\%), and the lowest in patients with partial epilepsy (23.5\%) [Kluger et al. 2009]. At 18 months, the overall seizure response rate was $26.7 \%$, with the highest subgroup still for LGS (35.5\%) [Kluger et al. 2010b]. Although still showing long-term efficacy, there was a slight decrease in this patient cohort from 12 weeks to 18 months. It was noted by the investigators that this could be explained by the fact that the efficacy of rufinamide may be more sustained in LGS than in partial epilepsy, as patients with LGS had the highest retention rates at 18 months $(51.6 \%)$, with only a $17.6 \%$ retention rate for patients with partial epilepsies.

In another retrospective study, 77 patients, with an age range of 1-27 years old (median 12 years old) with a variety of epilepsy syndromes were treated with adjunctive rufinamide, and followed for 1-10 months (median 4.4 months). The median maintenance dosing was $33.8 \mathrm{mg} / \mathrm{kg} /$ day. The overall seizure responder rate was $51 \%$, with responder rates of $48.6 \%$ for tonic-atonic seizures, and $46.7 \%$ for partial seizures [Vendrame et al. 2010]. In a separate retrospective review, 45 patients, with an age range of 1-20 years old (mean 9.5 years old), with a variety of epilepsy syndromes were treated with adjunctive rufinamide for 1 to 103 weeks (mean 21 weeks) [Joseph et al. 2011]. The mean maintenance dosing was $30.1 \mathrm{mg} / \mathrm{kg} /$ day. The overall seizure response rate was $46 \%$.

Our own experience has been similar. Using data collected retrospectively, 88 patients, with an age range of 2-43 years old (mean 12.1 years old), with a variety of epilepsy syndromes were treated with adjunctive rufinamide for a median duration of treatment of 9 months [Lee et al. 2012]. The average final dosing was $50-60 \mathrm{mg} / \mathrm{kg} /$ day. The overall seizure response rate was $54.6 \%$.

\section{Retrospective studies in focused \\ patient populations}

In a more focused retrospective study, Olson and colleagues examined the response to rufinamide in patients with epileptic spasms of varying etiologies [Olson et al. 2011]. A total of 38 patients, with an age range of 17 months to 23 years old (median 7 years old) were treated with adjunctive rufinamide for 10-408 days (median 171 days). The median maintenance dose was $39 \mathrm{mg} / \mathrm{kg} /$ day. The responder rate for epileptic spasms was $53 \%$. Furthermore, several small (3-8 patients) focused retrospective studies have provided encouraging clinical experiences using adjunctive rufinamide for other epilepsy syndromes. This includes epilepsy with myoclonic absences [Hausler et al. 2011], malignant migrating partial epilepsy of infancy [Vendrame et al.2011], myoclonic-astatic epilepsy (Doose syndrome) [von Stulpnagel et al. 2012], and a single case report with methylmalonic aciduria [von Stulpnagel et al. 2011].

A retrospective case series examining the use of adjunctive rufinamide for 20 patients with Dravet syndrome, however, reported low long-term efficacy, with a responder rate at 6 months of $20 \%$ and by 34 months the responder rate was $5 \%$ [Mueller et al. 2011]. Furthermore, seizure aggravation was reported by $30 \%$. Patients with Dravet syndrome have also been included in other studies with heterogeneous patient populations: Kluger and colleagues reported one out of two Dravet syndrome patients responding to rufinamide [Kluger et al. 2009], and Coppola and colleagues reported no patient responders out of four, although one patient was reported to have a $25-49 \%$ decrease in seizures [Coppola et al. 2011]. However, two of the patients with Dravet syndrome in this series had resultant seizure aggravation with rufinamide treatment.

\section{Safety and tolerability}

Of equal importance to the efficacy of rufinamide, in defining its clinical effectiveness, are safety and tolerability (Table 2). In the randomized placebocontrolled trial involving mostly children [Glauser 
et al. 2008], 60\% of patients in the rufinamide treatment group reported adverse events, of which the most common were somnolence $(24.3 \%)$, vomiting $(21.6 \%)$, pyrexia (13.5\%), and diarrhea $(5.4 \%)$. However, the only significant differences in adverse events when comparing the rufinamide-treated to the placebo group were somnolence $(24.3 \%$ with rufinamide versus $12.5 \%$ with placebo) and vomiting $(21.6 \%$ with rufinamide versus $6.3 \%$ with placebo). There were no reported clinical significant changes in vital signs, physical examinations, electrocardiogram recordings, or laboratory tests.

In a pooled analysis focusing on pediatric patients (less than 16 years old) treated with rufinamide within double-blind placebo-controlled studies drawn from a rufinamide clinical studies database, 212 patients were included for analysis [Wheless et al. 2009]. Of those in the rufinamide treatment group, $83.5 \%$ reported adverse events, of which the most common were somnolence ( $17 \%$ rufinamide versus $8.1 \%$ placebo), vomiting ( $16.5 \%$ versus $7.1 \%$ placebo), headache $(16 \%$ versus $8.1 \%$ placebo), and pyrexia ( $11.3 \%$ versus $10.7 \%$ placebo), with similar findings when the open-label extension patients were included. The majority of these adverse events were noted to be mild or moderate in severity. However, adverse events led to discontinuation in $7.1 \%$ in the double-blind rufinamide treated population (compared with $2 \%$ in the placebo population). Both the incidence and type of adverse events were similar across doses.

Within the pooled analysis, somnolence was the only cognitive adverse event occurring with an incidence of $10 \%$ or more [Wheless et al. 2009]. In a randomized, double-blinded, placebocontrolled study of patients consisting of older adolescents and adults within an age range of 15-64 years old, no serious cognitive effects were noted with 12 weeks of rufinamide treatment, measured using formal neuropsychological testing [Aldenkamp and Alpherts, 2006]. Although the applicability of this study to children cannot be assumed, it still reflects the low cognitive sideeffect profile of rufinamide.

The only contraindication listed in the rufinamide packet insert is familial short QT syndrome [Eisai Inc., 2010]. QTc-interval shortening can occur with rufinamide treatment, although complications are rare [Schimpf et al. 2012]. When compared against a placebo-treated population, however, the percentage of electrocardiograms that evolve from normal to abnormal after rufinamide treatment is similar, with $11.3 \%$ in the rufinamide group compared with $9.6 \%$ in the placebo group [Wheless et al. 2009].

In addition, within the pooled analysis, there were five patients identified with possible cases of antiepileptic drug hypersensitivity syndrome [Wheless et al. 2009]. All cases were quickly reversible with drug discontinuation. However, more severe reactions to include Stevens-Johnson syndrome have been reported with rufinamide use [Chambel et al. 2012].

\section{Drug-drug interactions}

Owing to its lack of effect upon the cytochrome P450 system, rufinamide has a relatively low potential for drug-drug interactions. In regards to interactions with other anticonvulsant medications, the data available on the pharmacokinetic interactions of rufinamide are derived from a retrospective pooled analysis from previous clinical trials of adjunctive rufinamide treatment [Perucca et al. 2008]. Rufinamide does not modify the clearance of topiramate or valproic acid. Rufinamide may slightly increase the clearance of carbamazepine and lamotrigine, and may slightly decrease the clearance of phenobarbital and phenytoin, with all predicted changes less than $17.5 \%$ [Perucca et al. 2008]. Lamotrigine and topiramate do not affect the clearance of rufinamide. Valproic acid, however, may decrease the clearance of rufinamide, with the most prominent effects occurring in children. This occurrence may be due to the fact that children are on higher doses of valproic acid, rather than an age-related effect [Perucca et al. 2008]. In clinical practice, rufinamide dosing in children taking concomitant valproic acid may need to be decreased, on average, by approximately $50 \%$ [Perucca et al. 2008].

\section{Pregnancy and teratogenicity}

Rufinamide may decrease blood levels of hormonal contraceptives, but the clinical significance of this is not known [Eisai Inc., 2010]. Rufinamide is labeled as a pregnancy category $\mathrm{C}$, owing to a lack of adequate well-controlled studies in women concerning pregnancy and teratogenicity. 


\section{Clinical use}

The decision-making process of choosing an anticonvulsant medication such as rufinamide to treat a child with epilepsy is led by the physician but should include active participation by the family, and when appropriate, the pediatric patient. This decision should consider the summation of known efficacy data, and the described safety and tolerability profile, but within the context of each individual patient. It is known that a patient's chances of seizure freedom decrease with each subsequent failed drug trial [Brodie et al. 2012], and thus many patients with LGS are medication-refractory. Other nonmedication treatments for epilepsy are available and should be considered in discussion with the family and patient, to include dietary and surgical options. However, this should not preclude the consideration of further anticonvulsant medication trials, if desired by the patient or their family, as remission in medication-refractory patients is still possible after the second drug failure, although often times temporary [Berg et al. 2009].

Rufinamide is now one of several anticonvulsant medications (felbamate, lamotrigine, topiramate, clobazam) that have demonstrated efficacy versus placebo in clinical trials for the treatment of LGS [The Felbamate Study Group in Lennox Gastaut, 1993; Motte et al. 1997; Sachdeo et al. 1999; Ng et al. 2011]. It should be appreciated, though, that although rufinamide demonstrates efficacy versus placebo in clinical trials, it cannot be concluded that it is superior to other anticonvulsant medications, due to a lack of head-to-head trials.

However, the treatment goal for the child with epilepsy is not only aimed at seizure control, but is ultimately focused upon the broader schema of enhancing and maximizing quality of life for the patient and their family. This is especially pertinent in LGS due to the tendency to be refractory to medication treatment. Although rufinamide has shown clinical efficacy in the defined parameters of clinical trials, seizure-freedom rates are low. Furthermore, there is a lack of qualitative research in LGS specifically addressing the effects of anticonvulsant drugs, to include rufinamide, on the health-related quality of life on the patient and the family [Gallop et al. 2009]. As seizures and cognitive impairment are the two main components influencing the health-related quality of life of children with LGS [Gallop et al. 2010], it is a reasonable goal to strive for optimal seizure control, although not at the expense of side effects which can negatively influence quality of life.

\section{Prescribing guidelines}

The FDA indication approves the use of rufinamide to a small focused population (adjunctive use in patients 4-years-old and over with LGS), as these are the only parameters in which randomized, double-blind, placebo-controlled data exists (Table 3). However, published data, as reviewed, support the safe and efficacious use of rufinamide outside both of these parameters, although this necessitates conscientious clinical judgment for each individual patient.

In the United States, rufinamide is available in $200 \mathrm{mg}$ tablets, $400 \mathrm{mg}$ tablets, and as a liquid suspension of $40 \mathrm{mg} / \mathrm{ml}$. The tablets can be taken whole, cut in half, or crushed. The plasma half-life of 6-10 hours allows for twice-daily dosing. Absorption and bioavailability appear to be hampered by the fasting states, and evidence supports increased absorption when taken with food [Perucca et al. 2008]. Thus, a practical recommendation is to take rufinamide twice daily with meals. An intravenous form of rufinamide is not available.

In terms of dosing, the clinical trial by Glauser and colleagues used a relatively quick titration schedule that was well tolerated, using an initial dosing of rufinamide $10 \mathrm{mg} / \mathrm{kg} /$ day in two divided doses and increasing by $10 \mathrm{mg} / \mathrm{kg}$ increments every other day to a target dosing within 7 days of $45 \mathrm{mg} / \mathrm{kg} /$ day or up to $3600 \mathrm{mg} /$ day (with some flexibility to extend the titration to 14 days as clinically needed) [Glauser et al. 2008]. This dosing recommendation is similar to the recommended dosing on the package insert [Eisai Inc., 2010]. However, in clinical practice, a slower titration schedule tends to be utilized, and appears to be better tolerated with similar efficacy [Vendrame et al. 2010; Kim et al. 2012]. In our personal experience treating a heterogeneous population of children with rufinamide, an initial dosing of 5-10 $\mathrm{mg} / \mathrm{kg} /$ day in two divided doses and increasing by $5-10 \mathrm{mg} / \mathrm{kg}$ increments every $5-7$ days to a maintenance dosing of $45-50 \mathrm{mg} / \mathrm{kg} /$ day is well tolerated without compromising efficacy [Lee et al. 2012]. Furthermore this allows time for assessment for those patients who might respond to, and could be maintained on, low doses of rufinamide.

Routine laboratory tests, such as blood counts or liver function testing, are not required with rufinamide treatment. There is a positive correlation between steady-state plasma levels and both seizure frequency and adverse effects, suggesting the possible clinical value of measuring plasma rufinamide levels [Perucca et al. 2008]. 
Table 3. Rufinamide clinical use summary.

\begin{tabular}{|c|}
\hline $\begin{array}{l}\text { FDA indication: } \\
\text { Adjunctive treatment of seizures associated with } \\
\text { Lennox-Gastaut syndrome in patients } 4 \text { years old } \\
\text { and older }\end{array}$ \\
\hline Clinical effectiveness: \\
\hline $\begin{array}{l}\text { Broad-spectrum, but especially efficacious for } \\
\text { tonic-atonic seizures associated with Lennox- } \\
\text { Gastaut syndrome }\end{array}$ \\
\hline Contraindications: \\
\hline Familial Short QT syndrome \\
\hline Most common side effects*: \\
\hline Fatigue \\
\hline Nausea and vomiting \\
\hline Decreased appetite \\
\hline Availability within the United States: \\
\hline $200 \mathrm{mg}$ tabs \\
\hline $400 \mathrm{mg}$ tabs \\
\hline $40 \mathrm{mg} / \mathrm{ml}$ liquid suspension \\
\hline Recommended dosing: \\
\hline Package insert: \\
\hline $\begin{array}{l}\text { Initial: } 10 \mathrm{mg} / \mathrm{kg} / \text { day in two divided doses, with } \\
\text { meals }\end{array}$ \\
\hline Increase by $10 \mathrm{mg} / \mathrm{kg}$ increments every other day \\
\hline $\begin{array}{l}\text { Maintenance: } 45 \mathrm{mg} / \mathrm{kg} / \text { day up to } 3600 \mathrm{mg} / \text { day in } \\
\text { two divided doses, with meals }\end{array}$ \\
\hline Clinical practice recommendation: \\
\hline $\begin{array}{l}\text { Initial: } 5-10 \mathrm{mg} / \mathrm{kg} / \text { day in two divided doses, with } \\
\text { meals }\end{array}$ \\
\hline Increase by $5-10 \mathrm{mg} / \mathrm{kg}$ increments every $5-7$ days \\
\hline $\begin{array}{l}\text { Maintenance: } 45-50 \mathrm{mg} / \mathrm{kg} / \mathrm{day} \text {, with meals, } \\
\text { adjusted as tolerated }\end{array}$ \\
\hline $\begin{array}{l}\text { *Somnolence and vomiting were the only adverse effects } \\
\text { more commonly reported with rufinamide treatment } \\
\text { with a significant treatment difference versus placebo } \\
\text { [Glauser et al. 2008]. }\end{array}$ \\
\hline
\end{tabular}

\section{Summary}

Rufinamide is proving to be a valuable medication treatment option in pediatric epilepsy, substantiated by efficacy and safety data from both clinical trials and clinical practice. In addition to a broad spectrum of clinical efficacy, it possesses many salient features that support its effectiveness in clinical practice, which can be of essential relevance when caring for children:

- a mild side-effect profile;

- twice a day dosing;

- both tablet and liquid formulations;

- the option of a quick titration;

- a low potential for drug-drug interactions;

- routine laboratory testing is not required.
However, further research and more clinical experience are needed to further define the role of rufinamide in the treatment of pediatric epilepsy. Although current research supports short-term clinical efficacy, data on the effects on quality of life, the underlying goal in the treatment of children with epilepsy, are lacking and should be addressed in future trials. Head-to-head trials with other anticonvulsant medications have not been performed, but would help to direct best practices. Finally, longterm efficacy and possible long-term adverse effects are undefined and will require continued monitoring. For now, rufinamide is asserted as an efficacious and well-tolerated adjunctive anticonvulsant medication for the treatment of refractory pediatric epilepsy, and should be considered particularly for refractory seizures associated with LGS.

\section{Funding}

This research received no specific grant from any funding agency in the public, commercial, or notfor-profit sectors.

\section{Conflict of interest statement}

The authors declare that there are no conflicts of interest.

\section{Disclaimer}

The views expressed are those of the authors and do not reflect the official policy or position of the United States Air Force, Department of Defense, or the U.S. Government.

\section{References}

Aldenkamp, A. and Alpherts, W. (2006) The effect of the new antiepileptic drug rufinamide on cognitive functions. Epilepsia 47: 1153-1159.

Berg, A., Levy, S., Testa, F. and D'Souza, R. (2009) Remission of epilepsy after 2 drug failures in children: a prospective study. Ann Neurol 65: 510-519.

Biton, V., Krauss, G., Vasquez-Santana, B., Bibbiani, F., Mann, A., Perdomo, C. et al. (2011) A randomized, double-blind, placebo-controlled, parallel-group study of rufinamide as adjunctive therapy for refractory partial-onset seizures. Epilepsia 52: 234-242.

Brodie, M., Barry, S., Bamagous, G., Norrie, J. and Kwan, P. (2012) Patterns of treatment response in newly diagnosed epilepsy. Neurology 78: 1548-1554.

Brodie, M., Rosenfeld, W., Vazquez, B., Sachdeo, R., Perdomo, C., Mann, A. et al. (2009) Rufinamide for the adjunctive treatment of partial seizures in adults 
and adolescents: a randomized placebo-controlled trial. Epilepsia 50: 1899-1909.

Camfield, P. (2011) Definition and natural history of Lennox-Gastaut syndrome. Epilepsia 52(Suppl. 5): 3-9.

Chambel, M., Mascarenhas, M., Regala, J., Gouveia, C. and Prates, S. (2012) Clinical Stevens-Johnson syndrome and rufinamide: a clinical case. Allergol Immunopathol [ePub ahead of print].

Coppola, G., Grosso, S., Franzoni, E., Veggiotti, P., Zamponi, N., Parisi, P. et al. (2010) Rufinamide in children and adults with Lennox-Gastaut syndrome: first Italian multicenter experience. Seizure 19: 587-591.

Coppola, G., Grosso, S., Franzoni, E., Veggiotti, P., Zamponi, N., Parisi, P. et al. (2011) Rufinamide in refractory childhood epileptic encephalopathies other than Lennox-Gastaut syndrome. Eur $\mathcal{F}$ Neurol 18: 246-251.

Eisai Inc. (2010) BANZEL ${ }^{\mathrm{TM}}$ Prescribing information. Eisai Inc., October 2010. Available at: http://www.banzel.com/pdf/BanzelPI.pdf (accessed 1 June 2012).

Elger, C., Stefan, H., Mann, A., Narurkar, M., Sun, Y. and Perdomo, C. (2010) A 24-week multicenter, randomized, double-blind, parallelgroup, dose-ranging study of rufinamide in adults and adolescents with inadequately controlled partial seizures. Epilepsy Res 88: 255-263.

French, J., Kanner, A., Bautista, J., Abou-Khalil, B., Browne, T., Harden, C. et al. (2004) Efficacy and tolerability of the new antiepileptic drugs II: treatment of refractory epilepsy: report of the Therapeutics and Technology Assessment Subcommittee and Quality Standards Subcommittee of the American Academy of Neurology and the American Epilepsy Society. Neurology 62: 1261-1273.

Gallop, K., Wild, D., Nixon, A., Verdian, L. and Cramer, J. (2009) Impact of Lennox-Gastaut Syndrome (LGS) on health-related quality of life (HRQL) of patients and caregivers: literature review. Seizure 18: 554-558.

Gallop, K., Wild, D., Verdian, L., Kerr, M., Jacoby, A., Baker, G. et al. (2010) Lennox-Gastaut Syndrome (LGS): development of conceptual models of healthrelated quality of life (HRQL) for caregivers and children. Seizure 19: 23-30.

Glauser, T., Kluger, G., Sachdeo, R., Krauss, G., Perdomo, C. and Arroyo, S. (2008) Rufinamide for generalized seizures associated with Lennox-Gastaut syndrome. Neurology 70: 1950-1958.

Hancock, E. and Cross, H. (2009) Treatment of Lennox-Gastaut syndrome. Cochrane Database Syst Rev 3: CD003277.
Hausler, M., Kluger, G. and Nikanorova, M. (2011) Epilepsy with myoclonic absences - favourable response to add-on rufinamide treatment in 3 cases. Neuropediatrics 42: 28-29.

Joseph, J., Schultz, R. and Wilfong, A. (2011) Rufinamide for refractory epilepsy in a pediatric and young adult population. Epilepsy Res 93: 87-89.

Kim, S., Eun, S., Kang, H., Kwon, E., Byeon, J., Lee, Y. et al. (2012) Rufinamide as an adjuvant treatment in children with Lennox-Gastaut syndrome. Seizure 21: 288-291.

Kluger, G., Glauser, T., Krauss, G., Seeruthun, R., Perdomo, C. and Arroyo, S. (2010a) Adjunctive rufinamide in Lennox-Gastaut syndrome: a longterm, open-label extension study. Acta Neurol Scand 122: 202-208.

Kluger, G., Haberlandt, E., Kurlemann, G., Ernst, J., Runge, U., Schneider, F. et al. (2010b) First European long-term experience with the orphan drug rufinamide in childhood-onset refractory epilepsy. Epilepsy Behav 17: 546-548.

Kluger, G., Kurlemann, G., Haberlandt, E., Ernst, J., Runge, U., Schneider, F. et al. (2009) Effectiveness and tolerability of rufinamide in children and adults with refractory epilepsy: first European experience. Epilepsy Behav 14: 491-495.

Lee, J., Bruno, P., Rabe, O., Thibert, R. and Thiele, E. (2012) Rufinamide treatment for refractory epilepsy in a largely pediatric population. $\mathcal{F}$ Pediatr Epilepsy 1: 97-101.

Moavero, R., Cusmai, R., Specchio, N., Fusco, L., Capuano, A., Curatolo, P. et al. (2012) Rufinamide efficacy and safety as adjunctive treatment in children with focal drug resistant epilepsy: the first Italian prospective study. Epilepsy Res [ePub ahead of print].

McLean, M., Schmutz, M., Pozza, M. and Wamil, A. (2005) The influence of rufinamide on sodium currents and action potential firing in rodent neurons. Epilepsia 46(Suppl. 8): 296.

Montouris, G. (2011) Rational approach to treatment options for Lennox-Gastaut syndrome. Epilepsia 52(Suppl. 5): 10-20.

Motte, J., Trevathan, E., Arvidsson, J., Nieto Barrera, M., Mullens, E., Manasco, P. et al. (1997) Lamotrigine for generalized seizures associated with the Lennox-Gastaut syndrome. N Engl F Med 337: 1807-1812.

Mueller, A., Boor, R., Coppola, G., Striano, P., Dahlin, M., von Stuelpnagel, C. et al. (2011) Low long-term efficacy and tolerability of add-on rufinamide in patients with Dravet syndrome. Epilepsy Behav 21: 282-284. 
Ng, Y., Conry, J., Drummond, R., Stolle, J., Weinberg, M., on behalf of the OV-1012 Study Investigators. (2011) Randomized, phase III study of results of clobazam in Lennox-Gastaut syndrome. Neurology 77: 1473-1481.

Olson, H., Loddenkemper, T., Vendrame, M., Poduri, A., Takeoka, M., Bergin, A. et al. (2011) Rufinamide for the treatment of epileptic spasms. Epilepsy Behav 20: 344-348.

Palhagen, S., Canger, R., Henriksen, O., van Parys, J., Riviere, M. and Karolchyk, M. (2001) Rufinamide: a double-blind, placebo-controlled proof of principle trial in patients with epilepsy. Epilepsy Res 43: 115-124.

Perucca, E., Cloyd, J., Critchley, D. and Fuseau, E. (2008) Rufinamide: clinical pharmacokinetics and concentration-response relationships in patients with epilepsy. Epilepsia 49: 1123-1141.

Sachdeo, R., Glauser, T., Ritter, F., Reife, R., Lim, P., Pledger, G. et al. (1999) A double-blind, randomized trial of topiramate in Lennox-Gastaut syndrome. Neurology 52: 1882-1887.

Schimpf, R., Veltmann, C., Papavassiliu, T., Rudic, B., Goksu, T., Kuschyk, J. et al. (2012) Drug-induced QT-interval shortening following antiepileptic treatment with oral rufinamide. Heart Rhythm 9: 776-781.

The Felbamate Study Group in Lennox-Gastaut Syndrome (1993) Efficacy of felbamate in childhood epileptic encephalopathy (Lennox-Gastaut

Visit SAGE journals online http://tan.sagepub.com

@SAGE journals syndrome). N Engl f Med 328: 29-33.

Vendrame, M., Loddenkemper, T., Gooty, V., Takeoka, M., Rotenberg, A., Bergin, A. et al.
(2010) Experience with rufinamide in a pediatric population: a single center's experience. Pediatr Neurol 43:155-158.

Vendrame, M., Poduri, A., Loddenkemper, T., Kluger, G., Coppola, G. and Kothare, S. (2011) Treatment of malignant migrating partial epilepsy of infancy with rufinamide: report of five cases. Epileptic Disord 13: 18-21.

Verrotti, A., Loiacono, G., Ballone, E., Mattei, P., Chiarelli, F. and Curatolo, P. (2011) Efficacy of rufinamide in drug-resistant epilepsy: a meta-analysis. Pediatr Neurol 44: 347-349.

von Stulpnagel, C., Coppola, G., Striano, P., Muller, A., Staudt, M. and Kluger, G. (2012) First long-term experience with the orphan drug rufinamide in children with myoclonic-astatic epilepsy (Doose syndrome). Eur F Paediatr Neurol [ePub ahead of print].

von Stulpnagel, C., Leichsenring, M., Muller, A., Staudt, M. and Kluger, G. (2011) Refractory focal epilepsy in a patient with methylmalonic aciduria: case report on positive and long-lasting effect of rufinamide. Neuropediatrics 42:71-73.

Wheless, J., Conry, J., Krauss, G., Mann, A., LoPresti, A. and Narurkar, M. (2009) Safety and tolerability of rufinamide in children with epilepsy: a pooled analysis of 7 clinical studies. $\mathcal{F}$ Child Neurol 24: 1520-1525.

White, H., Franklin, M., Kupferberg, H., Schmutz, M., Stables, J. and Wolf, H. (2008) The anticonvulsant profile of rufinamide (CGP 33101) in rodent seizure models. Epilepsia 49: 1213-1220. 